\title{
GIBSI: an integrated modelling system for watershed management - sample applications and current developments
}

\author{
R. Quilbé and A. N. Rousseau \\ Institut National de la Recherche Scientifique - Centre Eau, Terre et Environnement (INRS-ETE), Univ. du Québec, 490 rue \\ de la Couronne, Québec (QC), G1K 9A9, Canada
}

Received: 2 February 2007 - Published in Hydrol. Earth Syst. Sci. Discuss.: 4 June 2007

Revised: 27 August 2007 - Accepted: 30 October 2007 - Published: 22 November 2007

\begin{abstract}
Hydrological and pollutant fate models have long been developed for research purposes. Today, they find an application in integrated watershed management, as decision support systems (DSS). GIBSI is such a DSS designed to assist stakeholders in watershed management. It includes a watershed database coupled to a GIS and accessible through a user-friendly interface, as well as modelling tools that simulate, on a daily time step, hydrological processes such as evapotranspiration, runoff, soil erosion, agricultural pollutant transport and surface water quality. Therefore, GIBSI can be used to assess a priori the effect of management scenarios (reservoirs, land use, waste water effluents, diffuse sources of pollution that is agricultural pollution) on surface hydrology and water quality. For illustration purposes, this paper presents several management-oriented applications using GIBSI on the $6680 \mathrm{~km}^{2}$ Chaudière River watershed, located near Quebec City (Canada). They include impact assessments of: (i) municipal clean water program; (ii) agricultural nutrient management scenarios; (iii) past and future land use changes, as well as (iv) determination of achievable performance standards of pesticides management practices. Current and future developments of GIBSI are also presented as these will extend current uses of this tool and make it useable and applicable by stakeholders on other watersheds. Finally, the conclusion emphasizes some of the challenges that remain for a better use of DSS in integrated watershed management.
\end{abstract}

\section{Introduction}

Integrated water management at the watershed scale has become a priority in many countries all over the world. For instance, the U.S. Clean Water Act (see Clements et al., 1996;

Correspondence to: A. N. Rousseau

(alain.rousseau@ete.inrs.ca)
Gariépy et al., 2006) and the European Water Framework Directive (Official Journal of the European Community, 2000) impose specific objectives in terms of water resources integrity and have led to the creation of numerous watershed organisations that try to apply integrated management principles. These principles basically consist in conciliating all land and water uses while protecting and sustaining water resources. This relies on the involvement of stakeholders and the definition of operating rules. To facilitate the decision making process, there is a need for high quality and accessible data. In this context, scientific research has shifted towards the development of decision support systems (DSS) designed to support the implementation of integrated water management. DSS are practical and user-friendly computer tools that basically rely on a geographical information system (GIS) and a relational database management system (RDBMS) that enable the display of information at any point in space and time, as well as transforming raw data into information relevant to the decision making process (graphs, maps or tables). Most DSS are based on mathematical models and can be used to assess a priori the effect of watershed management scenarios regarding urban, forestry or agricultural issues, on water yield and quality at the watershed scale. Many DSS have been developed all over the world, suited for specific conditions, scales and purposes. Borah and Bera (2004) as well as Rousseau et al. (2005), to name a few, reviewed and compared some DSS. For instance, while some of them are more suited for urban water management, others are specifically developed to assess the effect of agricultural practices on hydrology. Even if most of them are still under development and regularly upgraded, their development is now advanced enough to envision concrete applications for water management purpose (e.g. see Borah and Bera, 2004; He, 2003; Rousseau et al., 2005; Santhi et al., 2001).

With the intent to illustrate the structure, development and possible applications of a DSS, this paper focuses on GIBSI (Gestion Intégrée des Bassins Versants à l'aide d'un Système

Published by Copernicus Publications on behalf of the European Geosciences Union. 


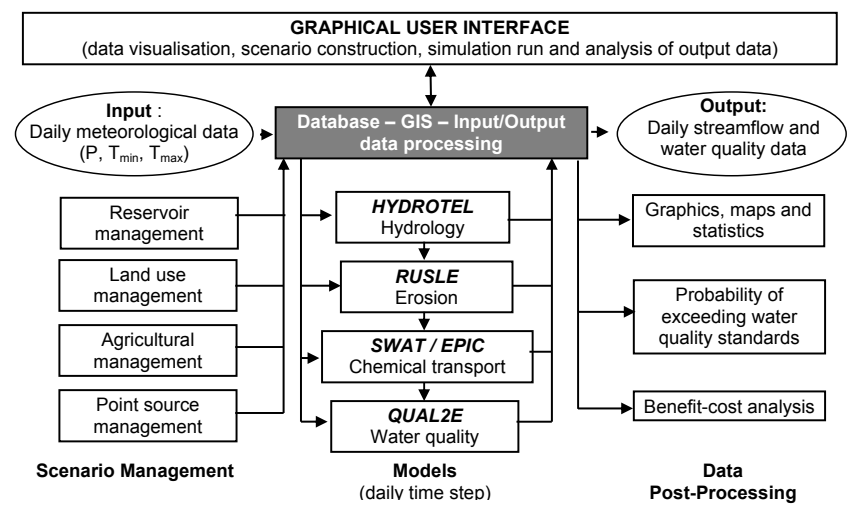

Fig. 1. Representation of GIBSI components and structure.

Informatisé), a Canadian DSS that was originally developed to assist scientists and stakeholders in integrated water management. The development of GIBSI began in 1995 and a first version was released in 1998 (Villeneuve et al., 1998a). A general description of GIBSI is presented in Sect. 2. Since 1998, several application studies have been conducted and some of them are briefly described in Sect. 3. At the same time, this integrated modelling system (IMS) has been continually upgraded by addition of new models, data postprocessing modules or model calibration guidelines. This is presented in Sect. 4. Note that GIBSI has been compared to other DSS by Quilbé et al. (2006) and Rousseau et al. (2005).

\section{General description of GIBSI}

GIBSI is designed to help stakeholders to make decisions in water management at the watershed scale. It can either be used as a data management system or as an impact assessment tool to study the effect of management scenarios on surface water quality using mathematical models. The general structure of GIBSI is depicted on Fig. 1. A detailed presentation of each component may be found in Villeneuve et al. (1998a).

\subsection{Data management modules}

As most DSS, GIBSI is basically composed of a database, a GIS, a RDBMS and a graphical user interface or GUI (Fig. 2). Attribute data were originally managed using Microsoft Access $^{\mathrm{TM}}$ (Simpson, 1994) but this RDBMS has now been replaced by the MySQL ${ }^{\circledR}$ database management system (Pedersen et al., 2005). The database contains spatial data (e.g. location of meteorological stations) and attribute data (i.e. all data associated with spatial data, such as meteorological series). The GIS used is GRASSLAND (L.A.S., 1996). The watershed is discretized into two types of computational elements: (i) river segments that is, one- dimensional elements that support watercourse simulation processes (i.e. streamflow and pollutant transport); and (ii) relatively homogeneous hydrological units (RHHUs) that is, elements corresponding to elementary watersheds that support all the other simulation processes (i.e. runoff generation and sediment and pollutant transport). These computational elements are determined using PHYSITEL (Turcotte et al., 2001), a complementary software program designed specifically to prepare the physiographic database of distributed hydrological models.

\subsection{Scenarios management modules}

Four types of management scenarios can be defined:

(i) Reservoirs: addition of new reservoirs at any river segment or editing of their characteristics;

(ii) Agriculture : editing of crop types, nutrient management practices, pesticide treatments, dates of agricultural practices, at any spatial scale (i.e. one or many RHHUs, subwatersheds or administrative units such as municipalities);

(iii) Wastewater treatment plants: addition of new plants at any river segment or editing of their characteristics (e.g. treatment types, effluent rates);

(iv) Land use: change of a land use class to another one at any spatial scale (Fig. 2).

Once scenarios are defined, they are integrated into the database and simulations can be run. In all studies, two scenarios are used: (i) a reference scenario that corresponds to the watershed configuration used for the model calibration, and (ii) a management scenario, integrating the changes defined by the user. Then, the simulation results obtained with the management scenario are always compared to those obtained with the reference scenario.

\subsection{Simulation modules}

GIBSI simulates hydrology, erosion, pollutant transport and surface water quality. It is based on four existing semidistributed models: (i) HYDROTEL (Fortin et al., 2001a; Fortin et al., 1995), a physically-based hydrological model compatible with GIS and remote sensing; (ii) RUSLE (Renard et al., 1997; Wischmeier and Smith, 1978) complemented by Yalin's equation (Yalin, 1963) to account for soil erosion and sediment transport capacity; (iii) the pollutant transport algorithms of SWAT (Arnold et al., 1996) and EPIC (Arnold and Williams, 1995) to simulate the fate of nitrogen, phosphorus and pesticides on cropland (note that the hydrological models of SWAT and EPIC are not used at all in GIBSI); (iv) QUAL2E (Brown and Barnwell, 1987) a water quality model that simulates the biological, physical and chemical processes controlling the fate of pollutants in surface water. The modeling time step is the day. Input data are 


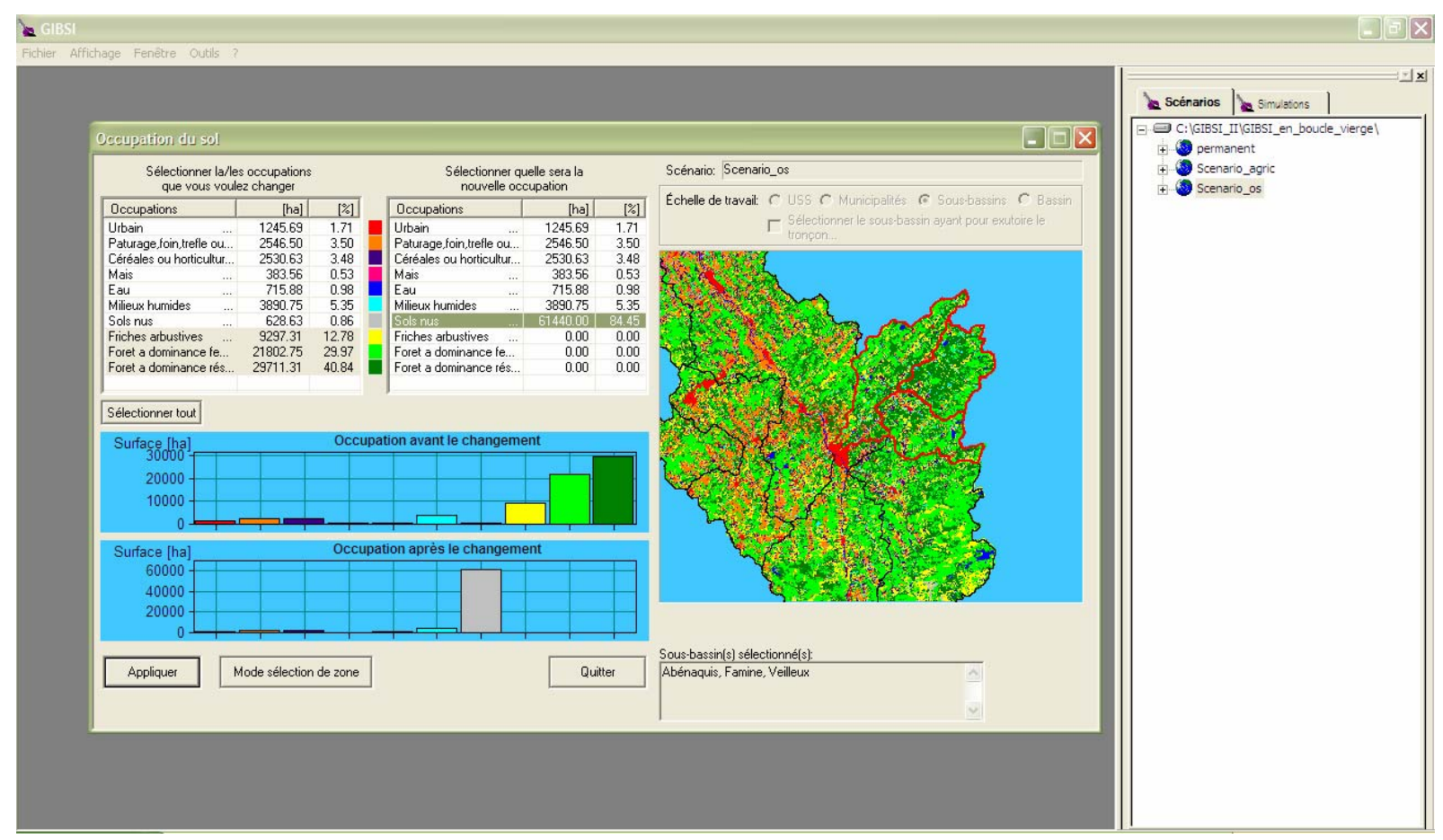

Fig. 2. Example of GIBSI window for the definition of land use management scenario.

daily meteorological series (precipitations, minimum temperature and maximum temperature). The user selects the meteorological series, either by defining dates of start and end into the meteorological database, or by selecting characteristic series.

\subsection{Post-processing tools}

Tools have been developed to analyse simulation results. First, data can be visualized using tables, graphs or maps. Regarding pollutant concentrations data, the frequency of exceeding a water quality standard can be calculated or visualised using graphs, which is useful when simulations concern the effect of management practices on specific water uses such as swimming or drinking water. Finally, an environmental benefit-cost analysis can be performed for agricultural scenarios based on the cost of implementation of agricultural beneficial management practices and the environmental benefits from recovering potential water uses due to water quality improvement (see Salvano et al., 2004). Note that simulation results obtained from the management scenario are always interpreted and analysed in relative terms with respect to those obtained with the reference scenario.

\section{Applications of GIBSI}

Several applications of GIBSI have been performed since the first version was released in 1998. All of these applications have been performed on the Chaudière River watershed or sub-watersheds. They dealt with : (i) the impact of a municipal clean water program on water quality (Mailhot et al., 2002, presented in Sect. 3.2); (ii) the effect of clear-cutting on the watershed hydrology (Lavigne et al., 2004); (iii) the determination of environmental load allocations from point and diffuse sources (Rousseau et al., 2002a, b); (iv) the environmental benefit-cost analysis of manure management (Salvano et al., 2004, 2006, presented in Sect. 3.3); (v) the influence of past and future land use on hydrology and erosion (Quilbé et al., 2007; Savary et al., 2007, presented in Sect. 3.4), and (vi) the definition of achievable agroenvironmental performance standards for pesticides (Rousseau et al., 2006, presented in Sect. 3.5).

The aim of this section is not to describe all of the above case studies in detail but rather to provide an overview of some of them with an emphasis on the range of possibilities and limitations of use of GIBSI.

\subsection{The Chaudière River watershed}

The Chaudière River is a tributary of the Saint-Lawrence River, located south of Québec City (Fig. 3). It drains a watershed of $6680 \mathrm{~km}^{2}$, mainly forested $(64 \%)$ and used for agriculture $(33 \%)$. This watershed was selected for the application and development of GIBSI due to the variety of land uses, agricultural and industrial activities, available data and because it is representative of many watersheds in the 


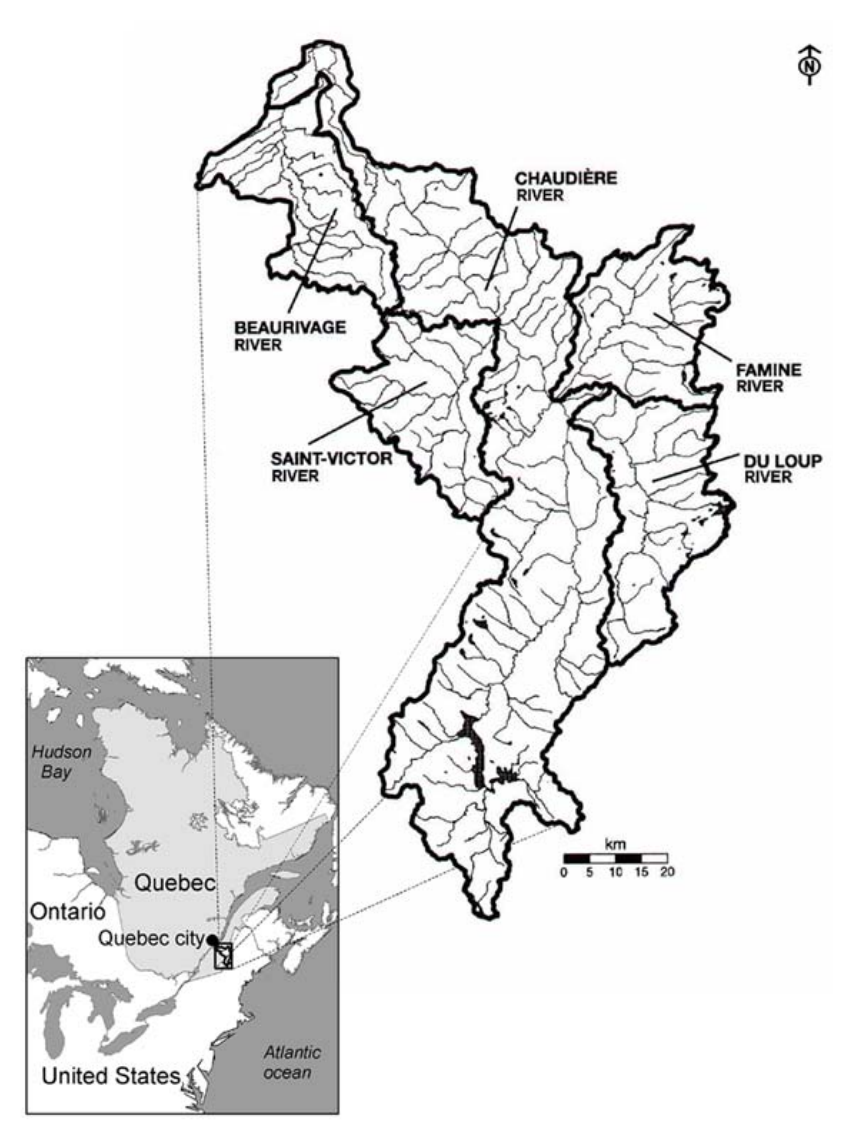

Fig. 3. Chaudière River watershed.

Saint-Lawrence valley. Soils vary from loamy sand in the downstream portion of the watershed to clay loam in the middle portion and loam in the upstream portion (Duchemin et al., 2001). Agriculture is dominated by animal production, especially pig and dairy farming. That implies that most of the cropland is dedicated to forages and pasture (75\% of agricultural land in 1995). It is also important to note that it was identified by the Québec government as the pilot watershed for the implementation of integrated watershed management in 1993. The population is now around 180000 inhabitants. Meteorological data come from forty stations distributed all over the watershed. Calibration of the hydrological model HYDROTEL was performed on the whole watershed (Fortin et al., 2001b) considering measured and simulated streamflows at the outlet. The model efficiency was satisfactory with Nash-Sutcliffe coefficients of 0.88 and 0.83 for 1989-1990 and 1993-1994, respectively. Spatial validation was performed for the Famine and Beaurivage subwatersheds with similar results. Temporal validations were also performed for years 1987-1988 and 1990-1991 as well as over a 10-yr period (see detailed results in Fortin et al., 2001b). A first calibration of the erosion model was performed in 2002 (unpublished). Regarding the nutrient transport and water quality model, Villeneuve et al. (1998b) compared simulated nitrate and phosphorus concentrations to measured data and found that errors were, in majority, less than $0.1 \mathrm{mgN} / \mathrm{L}$ and $0.01 \mathrm{mgP} / \mathrm{L}$ respectively. Results were less satisfactory, yet acceptable within a management scenario framework, for BOD5. Note that improvements and further calibration of these models are in progress (see Sect. 3.1).

\subsection{Impact of municipal clean water program}

\subsubsection{Context, objectives and general approach}

In 1978, a provincial municipal clean water program (MCWP) was implemented in Québec to control pointsource pollution and restore the province's surface water quality. On the Chaudière River watershed, 35 waste water treatment plants (WWTP) were built and the population being connected reached 95\% in 1997. The objective of this study (Mailhot et al., 2002) was to assess the effect of this program on water quality. The first step was to characterize WWTP properties (i.e. affluent and effluent water discharge, chemical and physical parameters). Pollutant loads from industrial plants not connected to a municipal sewer network as well as diffuse sources of pollution from urban area or agricultural land were not considered in this study.

\subsubsection{Scenarios and simulations}

Two scenarios were defined in GIBSI: the first one was associated with the 1983 year corresponding to the pre-MCWP period, and the second one was associated with the 1994 year describing the post-MCWP period. Simulations were performed with both scenarios using meteorological data of years 1983 (dry year) and 1994 (wet year) - two simulations for each scenario.

\subsubsection{Results}

Simulations results showed that the annual probability of exceeding phosphorus water quality standard (WQS) at the watershed outlet decreased from 0.53 to 0.40 after MCWP, under 1994 meteorological conditions (wet year). That corresponds to a gain of 49 days under the phosphorus WQS. The results are similar under dry conditions (1983 series), even if phosphorus concentrations remain almost always larger than the WQS during summer, and at the other control points on the watershed. Regarding biological oxygen demand (BOD5), the WQS was usually exceeded during several days in the year before MCWP. However, after MCWP, the standard was never exceeded, neither under wet nor dry conditions. Finally, we observed a decrease in median concentration but the concentrations were always less than the WQS, even before MCWP. We can conclude from this study that MCWP had a drastic effect on BOD5 and phosphorus but that urban wastewater is still responsible for high probabilities of exceeding phosphorus WQS in the Chaudière River. 


\subsubsection{Discussion}

This application study was relatively easy to implement since all the required data were available. However, it was based on several assumptions and simplifications that have to be taken into account. For instance, the possible overflow of unitary network as well as some natural sources of pollutants might have an influence on water quality but could not be taken into account by GIBSI. Moreover, the calibration of pollutant transport and water quality models of GIBSI was only partial at the moment of this study due to a lack of highresolution water quality data, with most of parameter values having generic values reported in literature. For instance, as indicated in Sect. 3.1, the BOD5 measured data were not well simulated by the water quality model during calibration process. Thus we have to make the assumption that this bias remains the same for the reference scenario and the management scenario for the interpretation of simulation results. Despite these limits, the use of a DSS like GIBSI was useful in this context to assess the efficiency of the municipal clean water program, at a lower cost than an extensive water quality survey.

\subsection{Environmental benefit-cost analysis of manure management}

\subsubsection{Context, objectives and general approach}

This study (Salvano et al., 2004, 2006) illustrates the importance of valuing environmental benefits associated with an improvement of water quality when assessing and implementing new agricultural nutrient management plans. In the province of Québec, the Québec Regulation Respecting Agricultural Operations (RRAO) was implemented in 2002 (and modified in 2005) to ensure the protection of water and soil, as well as aquatic life and human health from agricultural pollution. The rationale behind this regulation is to reach a balance between the soil's phosphorus support capacity and the amount of fertilizers. The objective of this study was to evaluate potential benefits generated from water quality improvements within a benefit/cost analysis framework. As most of human services provided by water are not priced in markets, their economic values first have to be estimated using non-market methods. In this case, a benefit transfer procedure was used (see Salvano et al., 2004, 2006 for details). As a first approximation, only the monetary benefits associated with water-based recreational activities were evaluated. First, willingness-to-pay and participation data (number of persons and days per person) were determined based on a survey from Environment Canada (Environment Canada, 2001). Then, the number of days exceeding the phosphorus aesthetic WQS obtained from simulations was used to calculate the total benefit of the management scenario.

\subsubsection{Scenarios and simulations}

This application concerned the Beaurivage River watershed (tributary of the Chaudière River) on which numerous river segments were identified for existing or potential recreational activities (swimming, canoeing, kayaking, hiking). Two scenarios were defined: (i) a base case scenario assuming application of all available manure; and (ii) an on-farm nutrient management scenario based on meeting phosphorus crop requirements with manure and treating any manure surpluses (so called RROA scenario). The cost associated with the implementation of this manure management practice was calculated based on livestock production costs and revenues, manure storage and treatment costs, and fertilization costs for a spatial unit, as compared to the base case scenario. A reduction of benefit is considered as an opportunity cost that is added to other costs. Total cost was then obtained by multiplying the unit cost by cropland area within management units of interest. Two types of spatial management units were considered to evaluate and compare the effect of these scenarios: a group of three contiguous municipalities and two subwatersheds corresponding to two river segments of the Beaurivage River watershed with existing or potential water uses. As the prime period for recreational activities is the summer, simulations were performed using summer meteorological data for years 1977 through 1986 independently.

\subsubsection{Results}

Simulations with the management scenario induced an increase of the number of days of potential activities (i.e. for which phosphorus concentration is lower than phosphorus aesthetic WQS) as compared to the base-case scenario, for the two river segments and the three management units (between 248 and 499 days vs. 213 days for base case scenario). The results of the environmental benefit-cost analysis are given in Table 1. We can see that benefits were similar for all management units but that costs were higher when implementing the scenario at the scale of the municipalities. It results in higher benefit-cost ratios, especially for the upstream river segment, due to the fact that it focuses on a problematic area. Note that all benefit-cost ratios were smaller than one, but a sensitivity analysis showed that this ratio could be larger than one when reducing manure treatment costs, which is technically achievable.

\subsubsection{Discussion}

The methodology used to estimate the benefits is based on several assumptions and does not take into account intrinsic values that would certainly increase the benefit-cost ratios. Thus, once again, the results have to be interpreted in a relative way by comparison of the different scenarios rather than as absolute values. However, the proposed environmental benefit-cost analysis methodology represents a first step 
Table 1. Results of the environmental benefit-cost analysis

\begin{tabular}{|c|c|c|c|c|c|}
\hline Scenario & Management unit & Total Benefits $^{1}(\$)$ & Net Benefits ${ }^{2}(\$)$ & Net $\operatorname{Costs}^{3}(\$)$ & Benefit-Cost Ratio \\
\hline Reference & Watershed & 34932318 & - & - & - \\
\hline \multirow[t]{3}{*}{ RRAO } & Municipalities & 39879554 & 4947236 & 13358754 & 0.37 \\
\hline & Subwatershed 1 & 39343865 & 4411547 & 6017262 & 0.73 \\
\hline & Subwatershed 2 & 40168706 & 5236388 & 9282867 & 0.56 \\
\hline
\end{tabular}

1 The benefits are for recreational activities associated with water use for both river segments.

2 That is the difference between the benefits of the scenario RRAO for the management unit with the benefits of the base-case scenario.

3 The costs were calculated for a management period of one-year.

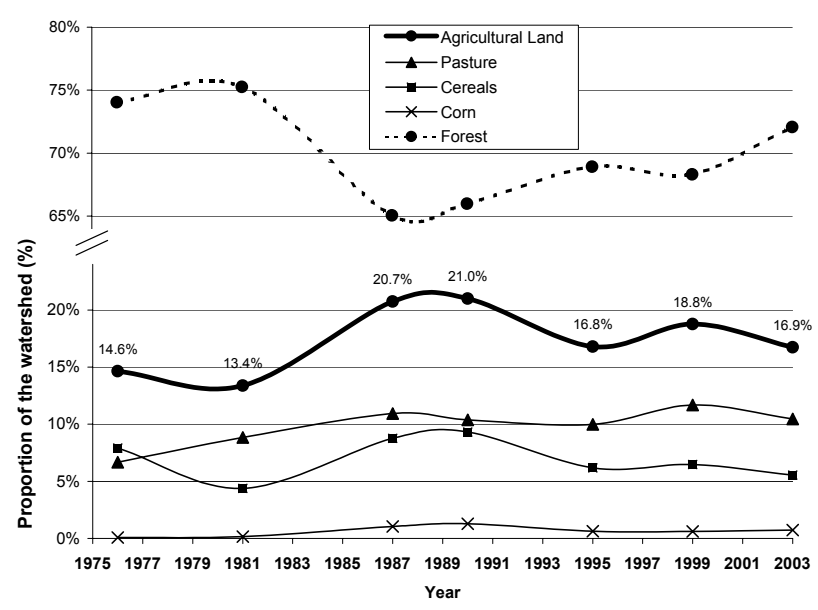

Fig. 4. Evolution of land use on the Chaudière River watershed from 1976 to 2004 .

towards the estimation of all monetary benefits of improving water quality (Yang et al., 2007).

3.4 Influence of past and future land use evolution on hydrological regime

\subsubsection{Context, objectives and general approach}

In general, land use all over the world has evolved a lot over the last decades, and it is important to understand and quantify the influence of these changes on hydrology in the past to be able to anticipate the future, especially in a climate change context. This is the objective of this study based on the application of GIBSI in the Chaudière River watershed (Savary et al., 2007¹; Quilbé et al., 2008).

\footnotetext{
${ }^{1}$ Savary, S., Rousseau, A. N. and Quilbé, R. Assessing the impact of past land use changes on runoff and low flows using remote sensing and distributed hydrological modeling - a case study for the Chaudière River watershed (Quebec, Canada), under review, 2007.
}

\subsubsection{Scenarios and simulations}

First, seven satellite images (Landsat) were acquired to reconfigure the evolution of land use over the last 30 years $(1976,1981,1987,1990,1995,1999,2004)$. After treatment and classification, the evolution of land use was quantified (Fig. 4). Agriculture and forest (including bush land) followed opposite tendencies, with an increase in agricultural land in the seventies, stagnation in the eighties and a decrease in the nineties. The seven images were integrated into the GIBSI database. For each land use configuration, simulations were run using 30 years of meteorological data (1970-1999), each year being considered independently.

For the prospective approach, the first step was to determine future meteorological sequences that would be used as input data in GIBSI. Three methods were used, based on general circulation models (GCM): delta method, statistical downscaling and a mix of both. Three GCMs were considered for the delta method and only one for the statistical downscaling method. Several gas emission scenarios (GES) were also considered for each case. Three land use scenarios were defined. First, the land use of 1995 was used as reference. Secondly, scenario A was driven by economical criteria, by extrapolating the last decade tendency regarding pig production increase. This results in deforestation to create more agricultural fields for feed production and manure application. Finally, scenario B considers the land use distribution as it was in 1976, implying reforestation. It also considers a spatial dispersion of agricultural lands over the watershed. Simulations were run with each scenario over $30 \mathrm{yrs}$ considered as independent, for reference period (1970-1999) and future period (2010-2039).

\subsubsection{Results}

Regarding the retrospective approach, the mean annual water discharge, as well as critical low flow sequences (Q2-7, Q107 and Q5-30), were strongly correlated with agricultural land use evolution, with determination coefficients of $0.97,0.95$, 0.92 and 0.93 , respectively. This can be explained by the fact that the increase in agricultural land to the detriment of forest induces less evapotranspiration, and thus more available 
water for overall runoff. Moreover, soil surface is more likely to produce faster runoff.

For the future, the results first show that, without any modification in land use (base case scenario), climate change would induce a decrease of annual water discharge at the outlet of the watershed (mean of $-2.7 \%$, with delta method). However, this value can be very different from a GCM/GES combination to another (from $-14.1 \%$ to $+13.8 \%$ ), pointing out the large uncertainties that are still linked to these methods. Water discharge would strongly increase in winter due to higher temperatures and earlier snow melt (on average $+68.5 \%$ ), and decrease the rest of the year (Fig. 5). When integrating land use evolution scenarios into GIBSI simulations, we obtained opposite effects between the two scenarios, with an increase and a decrease of water discharge in summer and fall, respectively. This is illustrated on Fig. 5 which shows the mean monthly water discharge obtained with GCM ECHAM4, GES A2 and the three land use scenarios (base case, A and B). These results suggest that intensification of agriculture (Scenario A) would mitigate the effect of climate change in summer and fall by generating more runoff and thus higher streamflow in river.

\subsubsection{Discussion}

This approach regarding the effect of climate change on hydrology has several limitations due to the methodology. First, only tendencies can be pointed out because of the uncertainty linked to the methods and tools used. Moreover, even if statistical downscaling captures precipitation occurrence, it is weaker at predicting rainfall amounts and extremes in our region (Gachon et al., 2005). Finally, short-term predictions provide a slight effect of climate change on hydrology which is difficult to distinguish from the GCM output variability. However, this study illustrates how a DSS like GIBSI, that includes a hydrological model and a land use scenario management module, enables to quantify the influence of past and future land use on the water regime of a river.

3.5 Definition of achievable agroenvironmental performance standards for pesticides at the watershed scale

\subsubsection{Context, objectives and general approach}

The Canadian National Agri-Environmental Standards Initiative (NAESI) program aims to develop water quality standards at the watershed scale, in order to lead the development and application of best management practices (BMPs) at the farm scale. This includes: (i) ideal performance standards (IPSs) that are based on ecotoxicological data and specify the desired level of environmental state needed to maintain ecosystem health, and (ii) achievable performance standards (APSs) which represent more realistic standards that could be achieved using recommended available processes, practices and technologies, including BMPs. This means that, to
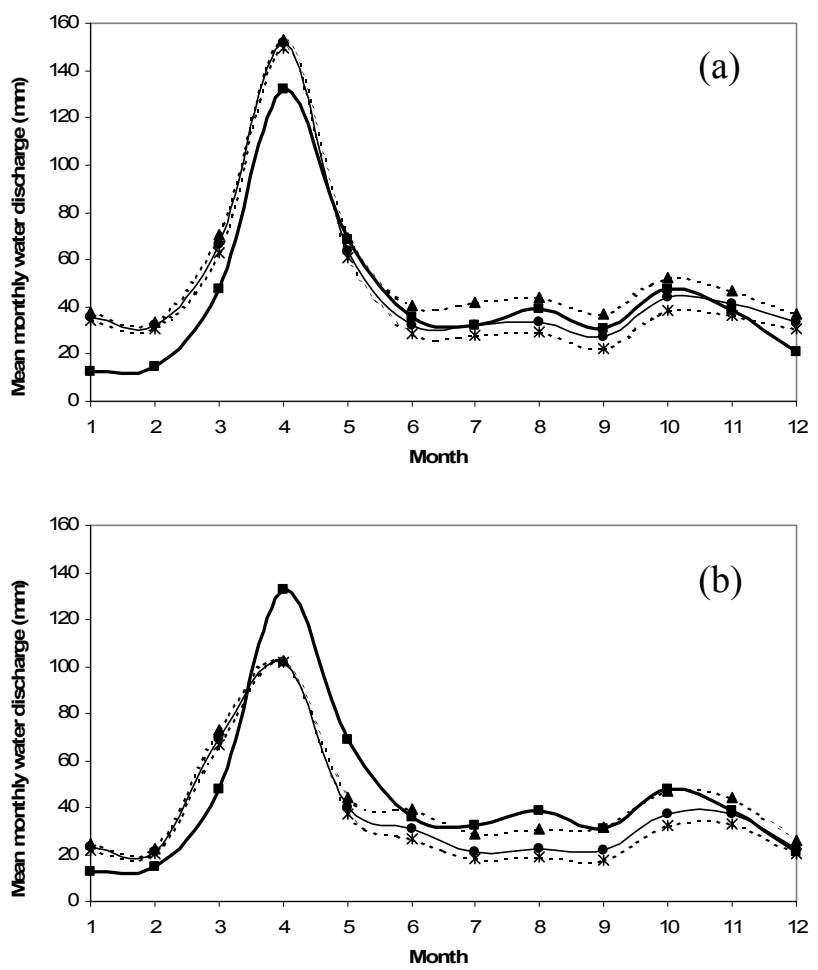

Fig. 5. Effect of climate change and land use evolution on mean monthly water discharge. Only the two GCM/GES combinations that give the extreme effects among all GCM/GES are considered here: HadCM3-A2b (a) and ECHAM4-A2 (b). In both cases, the bold line with squares represents the reference conditions as simulated by the model. Other lines represent future water discharge considering base case land use evolution scenario (thin line, circles), scenario A (dotted line, triangles) and scenario B (dotted line, stars).

determine APSs, it is necessary to assess a priori the effect of several BMPs on water quality by using a mathematical model that simulates the fate of pollutants at the watershed scale. This approach was first applied for pesticides. After a review and multicriteria comparative analysis of existing pesticide fate models at the watershed scale, GIBSI was selected together with the SWAT and BASINS/HSPF models (Quilbé et al., 2006). Pesticide concentrations data as well as representative agricultural practices were identified with a survey in the Beaurivage River watershed. However, due to the size of the area, it was impossible to identify precisely these practices at the farm scale. Therefore, a large uncertainty remains about the locations, dates and rates of pesticide applications. This uncertainty represents an important limitation for the calibration of the pesticide models. To account for this uncertainty during the simulations, a stochastic process was introduced in GIBSI to determine for each RHHU: (i) the year of crop rotation which determines the crop and thus what kind of pesticides are applied; and (ii) the date of application within the period of time defined. Then, 
Table 2. Q90 values (in $\mu \mathrm{g} / \mathrm{L}$ ) of Atrazine, MCPB and Metolachlor cumulative frequency curves obtained from GIBSI simulations.

\begin{tabular}{lcccc}
\hline & \multicolumn{3}{c}{ Scenario } & \\
& Base case & 1 & 2 & $1+2$ \\
& & $(1-m$ filter strip) & (application rate) & \\
\hline Atrazine & 0.454 & 0.080 & 0.060 & 0.026 \\
MCPB & 1.913 & 1.086 & 0.833 & 0.484 \\
Metolachlor & 0.423 & 0.179 & 0.133 & 0.000 \\
\hline
\end{tabular}

several simulations with different stochastic configurations for crops and application dates provide a range of pesticide concentrations in surface water.

\subsubsection{Scenarios and simulations}

This study is described by Rousseau et al. (2006). A base case scenario was defined based on current agricultural practices. We considered that pesticide applications were done between 1 and 15 June (16 days). The application rates were $0.65,0.06$ and $1.6 \mathrm{~kg} / \mathrm{ha}$ for Atrazine (on corn), MCPB (on cereals) and Metolachlor (on corn), respectively. Then three BMP scenarios were created based on this base case scenario: (1) implementation of a 1-m filter strip all along the river network; (2) a 30\% reduction in the pesticide application rate; and (3) a combination of both. Simulations were performed over thirty years (1979-1999), each year being considered independently. Three different stochastic configurations for crops spatial distribution and application dates were considered for each year, resulting in 90 simulations for each scenario. The effect of BMPs was examined at the outlet of the Beaurivage River subwatershed, which is the most affected by pesticide pollution.

\subsubsection{Results}

A cumulative frequency curve (CFC) of pesticide concentration was determined for the month of June since any pesticide level in the stream network beyond this month remains undetectable. We proposed to define the 90th centile (Q90) of this distribution as a possible value for APS. This means that this value is exceeded only $10 \%$ of the time. The results show that this value decreases with the implementation of BMPs (Table 2). For Atrazine, we observed a reduction of $81.7 \%$, $85.8 \%$ and $91.9 \%$ for scenarios 1, 2 and 3. For MCPB, the effect is weaker with a decrease of $41.4 \%, 47.5 \%$ and $74.7 \%$ respectively. Finally, for Metolachlor, Q90 was reduced of $57.6 \%, 68.6 \%$ and $100 \%$, respectively. It is noteworthy that all these concentrations values are all lower than the WQS for aquatic life protection $(1.8 \mu \mathrm{g} / \mathrm{L}, 7.3 \mu \mathrm{g} / \mathrm{L}$ and $8 \mu \mathrm{g} / \mathrm{L}$ respectively for Atrazine, MCPB and Metolachlor; MDDEP, 2006). These results mean that the effect of BMPs on pesticides concentrations may be very different from one pesticide to another. It should be noted that the final APS value can be linked to the ecotoxicologal impact by the use of a species sensitivity distribution (the one used for the determination of IPS) as a means to assess a priori the percentage of potentially affected species.

\subsubsection{Discussion}

The main difficulty encountered in this study was the lack of data regarding agricultural practices. Indeed, due to the size of the application watershed, it was impossible to know precisely the rates and dates of pesticide application all over the watershed. Thus, random variables had to be incorporated in the model so that a high-resolution calibration with measured pesticide concentrations was not possible. Nevertheless, this approach can be easily transposed to other pesticides and other rivers and watersheds, since it does not depend on watershed characteristics but only on data availability. The study shows the utility of tools like GIBSI to determine a priori the efficiency of management plans at the watershed scale and to define APSs. It also shows that such tools have to be easily adaptable to the user's needs.

\section{Current and future developments of GIBSI}

In parallel to these application studies, GIBSI has been continuously upgraded since the first version released in 1998. This concerned database management, interface, scenario management, post-processing tools and models.

\subsection{Model development and calibration}

Regarding models, only the calibration of the hydrological model has been reported in the literature (Fortin et al., 2001b). This explains why most of the applications presented in this paper concern the effect of watershed management on water discharge. Regarding the pollutant transport models (erosion, nutrients, pesticides), an important work was performed to improve them over the last three years, and their thorough calibration is currently in the process and results will be submitted for publication soon. Moreover, a pathogen transport model has been developed (Rogel, 2007). It simulates the fate of fecal coliforms resulting from manure application on crops as well as pasture, accounting for 
bacterial mortality, partitioning and transport in erosion and runoff.

Finally, an indicator of ecological integrity is currently under development (Grenier et al., 2006a). Indeed, physical and chemical data are not sufficient to determine the quality of an aquatic medium. For instance, high nitrogen and phosphorus concentrations in a stream or a lake indicate a risk for eutrophication but do not give information on the real state of the aquatic environment, which depends on many other factors such as $\mathrm{pH}$ or dissolved oxygen. This indicator will be based on benthic diatoms and macro-invertebrate communities. In a previous study (Grenier et al., 2006b), reference conditions of each stream type sampled in Southern Quebec (Canada) were defined using benthic diatoms and environmental variables characterizing streams and watersheds (regional reference site approach). Two diatom reference communities were sufficient to define reference conditions, one for neutral conditions and one for alkaline conditions. Based on these results, classification tree models (prediction models) were created using reference sites to identify watershed characteristics responsible for the discrimination between the two reference communities (neutral and alkaline). The model was then used to predict which diatom reference community should be present in an impacted stream under potential natural conditions. The results from this study were used to develop a diatom-based index that can be used to evaluate the degradation status of a site by comparing the actual ecological conditions with appropriate reference conditions. The same approach is now being applied for benthic macroinvertebrate communities ${ }^{2}$. Finally, the developed models will be integrated into GIBSI to predict the structure of diatoms and macro-invertebrate communities in rivers based on simulated physical and chemical variables.

\subsection{Development of an application protocol of GIBSI and} implementation on other watersheds

GIBSI has been developed and applied on the Chaudière River watershed. A user's guide already exists (Villeneuve et al., 2003) but it only explains how to use GIBSI once it is implemented. However, the implementation and application procedure of GIBSI, like many DSS, is still complex and follows several steps that have to be done carefully, for example: identification of user's needs, model selection, data acquisition, database construction, model adaptation if needed, model calibration, scenario definition, simulations and result analysis. Thus, the amount of effort varies a lot depending on available data or required adaptation. In the simplest case, when all needed data are available in the correct formats, it takes about three months for a team of two full-time research assistants to set up the database to calibrate the models (when

\footnotetext{
${ }^{2}$ Grenier, M., Pelletier, L., Rousseau, A. N., and Campeau, S.: Establishing Benthic Macroinvertabrate Reference Communities for the Evaluation of Aquatic Ecosystem Degradation: comparison of a priori and a posteriori approaches, under review, 2007
}

no adaptation is required). Moreover, it should be always kept in mind that all models are based on simplification hypotheses that have to be considered in the end of the process, i.e. when interpreting the results and conclusions. Therefore, in order to allow stakeholders to apply GIBSI on other watersheds, an application protocol is being developed, explaining the different steps to follow and giving tools to clarify the procedure. It includes an inventory of needed data, a dictionary of the database and a guide on how to construct the database, discretize the watershed, apply and calibrate the models. Moreover, these two documents (user's guide and application protocol) as well as the GUI will eventually be translated in English and Spanish.

Meanwhile, applications on other watersheds abroad have already begun: GIBSI is now being implemented on a Mexican watershed (Arcediano watershed, Santiago River) by the Instituto Mexicano de Tecnología del Agua (IMTA). The objective is to improve water management on this watershed, in collaboration with the watershed management committee. Moreover, GIBSI is also in the implementation process on four watersheds throughout Canada to determine APSs for pesticides (see Sect. 3.8): Yamaska river (QC), Wilmot-Dunk (PEI), South Nations (ON) and Salmon Arm (CB).

\section{Discussion and conclusion}

The practical applications of GIBSI presented in this paper illustrate the wide range of possibilities offered by such a tool to assess the effect of land use management, wastewater treatment or agricultural practices on water quantity and quality at the watershed scale. They also illustrate the difficulties and limitations that can be encountered when using a DSS, due to modeling or methodological assumptions, scenario construction, and lack of data or unsatisfying calibration results. Thus, it is very important to identify and consider these limitations, which are specific to each DSS, when, at first, choosing a DSS that is suited to user's needs and when, at last, interpreting simulations results. These two steps are certainly the most difficult and crucial ones in the whole application procedure. Note also that, due to these limitations, results interpretation should always be done in a relative way, comparing a management scenario to a reference scenario, and not as absolute results.

The application of a DSS is a dynamic process since most of them are constantly upgraded or complemented by new modules. In the case of GIBSI, current and future works involve addition and calibration of models as well as development of a water ecological integrity indicator.

More generally, this paper demonstrates how a DSS may be used to incorporate sound science into legislative and political decisions regarding water management. However, the integration and the use of a DSS for operational integrated watershed management issues still face major challenges. One of them is that DSS are often too complex for 
operational purposes. Indeed, if stakeholders do need tools that are sound science based, they also need them to be easy to use, apply and understand. Thus, this requires a simplification as well as the development of tools and guides that facilitate the technical transfer from research to management, as it is being done for GIBSI. Also, new concepts based on user needs and receptivity have to be investigated (see Jakeman and Letcher, 2003; McIntosh et al., 2007). Moreover, the uncertainty in model outputs has to be quantified to make the DSS more reliable and the decision making process easier (Mannina et al., 2006; Wu et al., 2006). Even so, it is clear that DSS application will always need a close dialogue between users and developers, i.e. between stakeholders and scientists, within an interdisciplinary framework, and this is certainly one of the greatest interests of such tools.

Acknowledgements. The development of GIBSI was funded by grants from the Québec Ministry of Environment (1995-1998; 1999-2002) and the Fonds québécois de la recherche sur la nature et les technologies (FQRNT, 2004-2007). The application on the influence of land use has been funded by Natural Resources Canada's Climate Change Action Fund (CCAF) and OURANOS, a Québec Research Consortium on Regional Climatology and Adaptation. The application regarding development of APSs for pesticides is funded by Environment Canada and Centre SaintLaurent. The authors would like to thank S. Savary, M. Grenier, G. Rogel, M.-P. Lavigne, S. Ricard, M. S. Garbouj, J.-S. Moquet, S. Tremblay (INRS-ETE) and E. Salvano (University of Manitoba) for their contribution to this paper. Special thanks to A. Mailhot who has contributed from the start and to J.-P. Villeneuve who has initiated the development of GIBSI in 1995.

Edited by: R. Moussa

\section{References}

Arnold, J. G. and Williams, J. R.: The EPIC model, in: Computer models of watershed hydrology, edited by: Singh, V. P., Water Resources Publications, Highlands Ranch, CO, 847-908, 1995.

Arnold, J. G., Williams, J. R., Srinivasan, R., and King, K. W.: SWAT. Manual, USDA, Agricultural Research Service and Blackland Research Center, Texas, 1996.

Borah, D. K. and Bera, M.: Watershed-scale hydrologic and nonpoint-source pollution models: review of applications, Transactions of the ASAE, 47(3), 789-803, 2004.

Brown, L. C. and Barnwell, T. O. J.: The enhanced stream water quality models QUAL2 and QUAL2E-UNCAS: Documentation and User Manual, Environmental Protection Agency, Athens, Georgia, U.S., 1987.

Clements, J. T., Creager, C. S., Beach, A. R., Butcher, J. B., Marcus, M. D., and Schueler, T. R.: Framework for a watershed management program, Water Environment Research Foundation, Alexandria, 1996.

Duchemin, M., Rousseau, A. N., Lamontagne, L., and Villeneuve, J.-P.: Utilisation des technologies géomatiques pour spatialiser le facteur K d'érodabilité des sols du bassin versant de la rivière Chaudière, Québec, Can. J. Soil Sci., 81, 423-437, 2001.
Environment Canada: The importance of Nature to Canadians: The economic significance of Nature-related activities, FederalProvincial-Territorial Task Force for the Importance of Nature to Canadians, En 47-312/2000E, Ottawa, 2001.

Fortin, J., Turcotte, R., Massicotte, S., Moussa, R., Fitzback, J., and Villeneuve, J.-P.: A distributed watershed model compatible with remote sensing and GIS data, Part I: Description of the model, J. Hydraulic Eng., 6(2), 91-99, 2001a.

Fortin, J. P., Moussa, R., Bocquillon, C., and Villeneuve, J.-P.: Hydrotel, un modèle hydrologique distribué pouvant bénéficier des données fournies par la télédétection et les systèmes d'information géographique, Revue des Sciences de 1'Eau, 8(1), 97-124, 1995.

Fortin, J. P., Turcotte, R., Massicotte, S., Moussa, R., and Fitzback, J.: A distributed watershed model compatible with remote sensing and GIS data, part 2: Application to the Chaudière watershed, J. Hydraulic Eng., 6(2), 100-108, 2001 b.

Gachon, P., St-Hilaire, A., Ouarda, T., Nguyen, V. T. V., Lin, C., Milton, J., Chaumont, D., Goldstein, J., Hessami, M., Nguyen, T. D., Selva, F., Nadeau, M., Roy, P., Parishkura, D., Major, D., Choux, M., and Bourque, A.: A first evaluation of the strength and weaknesses of statistical downscaling methods for simulating extremes over various regions of eastern Canada, Final report, Sub-component, Climate Change Action Fund (CCAF), Environment Canada, Montréal, Québec, Canada, 2005.

Gariépy, S, Rousseau, A. N., and Brun, A.: La gestion de l'eau par bassin versant aux Etats-Unis : entre incitatifs législatifs et intérêts des usagers, in: Les politiques de l'eau, grands principes et réalitées locales, edited by: Brun, A. and Lasserre, F., Ed. PUQ, coll. Géographie contemporaine, 69-90, 2006.

Grenier, M., Campeau, S., and Rousseau, A. N.: Establishing diatom reference communities in Quebec streams (Canada): ecological goals for stream restoration and baseline for evaluation of aquatic ecosystem degradation status, Man and River Systems II - Interactions among Rivers, their Watersheds, and the Socioecosystem, Extended abstracts - International Symposium, Paris, December 4-6, 2006, Presses de l'École Nationale des Ponts et Chaussées, 102-104, 2006a.

Grenier, M., Campeau, S., Lavoie, I., Park, Y. S., and Lek, S.: Diatom reference communities in Québec (Canada) streams based on Kohonen self-organizing maps and multivariate analyses, Can. J. Fish. Aquat. Sci., 63, 2087-2106, 2006 b.

$\mathrm{He}, \mathrm{C}$. : Integration of geographic information systems and simulation model for watershed management, Environ. Modell. Software, 18(8-9), 809-813, 2003.

Jakeman, A. J. and Letcher, R. A.: Integrated assessment and modelling: features, principles and examples for catchment management, Environ. Modell. Software, 18(6), 491-501, 2003.

Logiciels et Applications Scientifiques Inc. (L. A. S.): Grassland User's guide for Windows95 and Windows NT, Version 1.0, Montréal, QC., 1996.

Lavigne, M.-P., Rousseau, A. N., Turcotte, R., Laroche, A. M., Fortin, J.-P., and Villeneuve, J.-P.: Validation and use of a distributed hydrological modeling system to predict short term effects of clear cutting on the hydrological regime of a watershed, Earth Interactions, 8(3), 1-19, 2004.

Mailhot, A., Rousseau, A. N., Salvano, E., Turcotte, R., and Villeneuve, J.-P.: Évaluation de l'impact de l'assainissement urbain sur la qualité des eaux du bassin versant de la rivière Chaudière 
à l'aide du système de modélisation intégrée GIBSI, Revue des Sciences de 1'Eau, 15, 149-172, 2002.

Mannina, G., Freni, G., Viviani, G., Sægrov, S., and Hafskjold, L. S.: Integrated urban water modelling with uncertainty analysis, Water Sci. Technol., 379-386, 2006.

McIntosh, B. S., Seaton, R. A. F., and Jeffrey, P.: Tools to think with? Towards understanding the use of computer-based support tools in policy relevant research, Environ. Modell. Software, 22(5), 640-648, 2007.

Ministère du Développement Durable, de l'Environnement et des Parcs du Québec (MDDEP):http://www.mddep.gouv.qc.ca/eau/ criteres_eau/critere_lmc.htm\#mcpb, 2006

Official Journal of the European Community: Directive 200/60/EC of the European Parliament and of the Council of 23 October establishing a framework for Community action in the field of water policy, OJ C L 327, 22.12.2000, 2000.

Pedersen, C., Dubois, P., and Hinz, C.: MySQL 5, Certification Study Guide, MySQL Press, 2005.

Quilbé, R., Rousseau, A. N., Lafrance, P., Leclerc, J., and Amrani, M.: Selecting a pesticide fate model at the watershed scale using a multi-criteria analysis, Water Quality Res. J. Can., 41(3), 283295, 2006.

Quilbé, R., Rousseau, A. N., Moquet, J.-S., Savary, S., Ricard, S., and Garbouj, M. S.: Hydrological responses of a watershed to historical land use evolution and future land use scenarios under climate change conditions, Hydrol. Earth Syst. Sci. Discuss., 4, 1337-1367, 2007, http://www.hydrol-earth-syst-sci-discuss.net/4/1337/2007/.

Renard, K. G., Foster, G. R., Weesies, G. A., Mclood, D. K., and Yoder, D. C.: Predicting Soil Erosion by Water : A Guide to Conservation Planning with the Revised Universal Soil Loss Equation (RUSLE), US Department of Agriculture, Washington, 1997.

Rogel, G.: Développement et intégration au système de modélisation intégré GIBSI d'un modèle de transport et du devenir d'agents pathogènes d'origine agricole à l'échelle du bassin versant, Master Thesis in Water Science, INRS-ETE, University of Québec, Québec City, Canada, 2007.

Rousseau, A. N., Mailhot, A., Gariépy, S., Salvano, E., and Villeneuve, J.-P.: Calcul de probabilités de dépassement d'objectifs environnementaux de rejets de sources ponctuelle et diffuse à l'aide du système de modélisation intégrée GIBSI, Revue des Sciences de l'Eau, 15, 121-148, 2002a.

Rousseau, A. N., Mailhot, A., Quilbé, R., and Villeneuve, J.P.: Information technologies in a wider perspective: integrating management functions across the urban-rural interface, Environ. Modell. Software, 20(4), 443-455, 2005.

Rousseau, A. N., Mailhot, A., and Villeneuve, J.-P.: Development of a risk-based TMDL assessment approach using the integrated modeling system GIBSI, Water Sci. Technol., 45(9), 317-324, 2002b.

Rousseau A. N., Quilbé, R., Lafrance, P., Savary, S., Amrani, M., Caux, P.-Y., and Jiapizian, P.: A hydrological modelling framework for defining watershed-scale achievable performance standards of pesticides beneficial managements practices. Man and River Systems II - Interactions among Rivers, their Watersheds, and the Socioecosystem. Extended abstracts - International Symposium, Paris, 4-6 December 2006, Presses de l'École Nationale des Ponts et Chaussées, 193-194, 2006.
Salvano, E., Rousseau, A. N., Debailleul, G., and Villeneuve, J.-P.: Development of a cost-benefit framework to evaluate the impact of legislation supporting reduction of agricultural pollution at the watershed level, in: Lake Champlain in Transition: Partnerships in Progress, edited by: Manley, T. O., Manley, P. L., and Mihuc, T., Kluwer Academic, 123-142, 2004.

Salvano, E., Rousseau, A. N., Debailleul, G., and Villeneuve, J.P.: An environmental benefit-cost analysis case study of nutrient management in an agricultural watershed, Can. J. Water Resour., 31(2), 105-122, 2006.

Santhi, C., Arnold, J. G., Williams, J. R., Hauck, L. M., and Dugas, W. A.: Application of a watershed model to evaluate management effects on point and nonpoint source pollution, Transactions of the ASAE, 44(6), 1559-1570, 2001.

Simpson, A.: Microsoft Access 2, Sybex Inc., San Francisco, CA, 1994.

Turcotte, R., Fortin, J.-P., Rousseau, A. N., Massicotte, S., and Villeneuve, J.-P.: Determination of the drainage structure of a watershed using a digital elevation model and a digital river and lake network, J. Hydrol., 240(3-4), 225-242, 2001.

Villeneuve, J.-P., Blanchette, C., Duchemin, M., Gagnon, J.-F., Mailhot, A., Rousseau, A. N., Roux, M., Tremblay, J. F., and Turcotte, R.: Rapport Final du Projet GIBSI : Gestion de l'Eau des Bassins Versants à l'Aide d'un Système Informatisé. Mars 1998: Tome 1., R-462, INRS - Eau, Sainte-Foy, 1998 a.

Villeneuve, J.-P., Blanchette, C., Duchemin, M., Mailhot, A., Rousseau, A. N., Roux, M., Trépanier, S., and Turcotte, R.: Document relatif aux commentaires du Comité de suivi du projet GIBSI, 462 Add1, INRS - Eau, Sainte-Foy, 1998b.

Villeneuve, J.-P., Rousseau, A. N., Mailhot, A., Salvano, E., Simard, B., Corriveau, R., and Tremblay, S.: Guide de l'usager de GIBSI (Version II - 2003), R-549-g2, INRS-ETE, Sainte-Foy (QC), Canada, 2003.

Wischmeier, W. H. and Smith, D. D.: Predicting rainfall erosion losses - A guide to conservation planning, Agricultural Handbook No. 537, U.S. Department of Agriculture, Washington, D.C., 1978.

Wu, J., Zou, R., and Yu, S. L.: Uncertainty analysis for coupled watershed and water quality modeling systems, J. Water Resour. Planning Manage., 132(5), 351-361, 2006.

Yalin, Y. S.: An expression for bed-load transportation, J. Hydr. Eng. Div.-asce, 89, 221-250, 1963.

Yang, W., Rousseau, A. N., and Boxall, P.: An integrated, economic-hydrologic, modeling framework for the watershed evaluation of beneficial management practices, J. Soil Water Conserv., Nov.-Dec., 423-432, 2007. 